„Analecta Cracoviensia” 47 (2015), s. 25-40

DoI: http://dx.doi.org/10.15633/acr.1747

ks. Jan Machniak

Universidad Pontificia de Juan Pablo II de Cracovia

\title{
La devocion a la Divina Misericordia segun Santa Faustina Kowalska
}

La canonización de la Hermana Faustina Kowalska el 30 de abril de 2000 por Juan Pablo II y la institución de la Fiesta de la Divina Misericordia para toda la Iglesia católica pone a la Iglesia en Polonia en una nueva situación. La elevación a la gloria de los altares de la Hermana Faustina es, al mismo tiempo, una muestra para el mundo del camino hacia Dios y de la devoción a la Divina Misericordia como el modo de rendir culto a Dios. La Hermana Faustina propone un nuevo modelo de espiritualidad basado en la experiencia del misterio de la misericordia de Dios que tiene a la vez un carácter de pasión y pascua. La Mística de Cracovia no deja de proclamar el mensaje de la misericordia que le entregó Jesucristo en las revelaciones privadas, recordando al mundo que Dios es misericordioso y cuyo culmen de esta verdad es la muerte y resurreción de Cristo.

La Apóstol de la Divina Misericordia transmite también las formas concretas de la devoción a la Divina Misericordia como el modo de rendir culto a Dios misericordioso. En las nuevas formas de devoción transmitidas por Santa Faustina ocupa un lugar central la actitud de confianza, así como el culto rendido a la imagen de Jesús misericordioso, la celebración de la Fiesta de la Misericordia, el rezo de la Coronilla y el cumplimiento de las obras de misericordia ${ }^{1}$.

\footnotetext{
Sobre la temática de la devoción a la Divina Misericordia existe hoy en día una rica literatura. Recordamos tan solo las obras más importantes: I. Różycki, Nabożeństwo do Bożego Miłosierdzia, Kraków 1999; A. Witko, Nabożeństwo do Miłosierdzia Bożego, wedtug bł. Faustyny Kowalskiej, Kraków 1995; Cz. Domin, Kult Miłosierdzia Bożego w kościele dawniej i po objawieniu Sługi Bożej S. Faustyny, [en:]
} 
Abordando el tema delas nuevas formas de devoción a la Divina Misericordia en el mensaje transmitido al mundo por la Hermana Santa Faustina Kowalska, tenemos que explicar en primer lugar el mismo concepto de devoción que entraña un significado muy rico en la teología, sobre todo en la liturgia, así como en la espiritualidad. A continuación vamos a presentar el problema de la esencia de la devoción a la Divina Misericordia. A continuación vamos a tratar las formas concretas de la oración que transmitió Jesucristo en las revelaciones a Santa Faustina. Finalmente vamos a abordar la cuestión de las promesas de Jesucristo relacionadas con el cumplimiento de las condiciones de esta devoción.

\section{El concepto de devoción}

La devoción, entendida ampliamente como piedad, es una forma de culto mediante la cual el creyente adora a Dios en persona, revelado en plenitud en Jesucristo y dándose a conocer gracias a la actuación del Espíritu Santo ${ }^{2}$. Comprende la actitud interior de profunda veneración y amor hacia Dios como Creador y Padre misericordioso (donum pietatis), los actos de culto dirigidos hacia Dios provenientes del culto interior y de la actitud hacia el prójimo, todo ello motivado por el amor al prójimo ${ }^{3}$. A la devoción así entendida pertenecen los actos conscientes y las actitudes exteriores cuyo primer y último fin es confesar y rendir culto a Dios en Su total soberanía. El culto así entendido puede tener un carácter privado y entonces es definido con el concepto de piedad, o bien adopta un aspecto público, reconocido oficialmente por la Iglesia, convirtiéndose en una parte de la liturgia.

El Concilio Vaticano i en la Constitución sobre la sagrada liturgia, $\mathrm{Sa}$ crosanctum Concilium, resaltó el hecho de que el culmen del culto cristiano es el misterio pascual «de la bienaventurada Pasión, Resurreción de entre los

Posłannictwo Siostry Faustyny, red. Cz. Drążek sı, Kraków 1988, p. 155-178; E. Siepak, Kult Miłosierdzia Bożego w Zgromadzeniu Sióstr Matki Bożej Miłosierdzia, [en:] Posłannictwo Siostry Faustyny, obra citada, p. 247-264. S. Koperek, Przesłanie o Miłosierdziu Bożym w liturgii II Niedzieli Wielkanocy, [en:] Święto Miłosierdzia Bożego, red J. Machniak, Kraków 1966, p. 27-42; P. Ptasznik, Liturgiczne święto jako szczytowy wyraz nabożeństwa de Miłosierdzia Bożego, [en:] Święto Miłosierdzia Bożego, obra citada, p. 55-70; S. Smoleński, Wewnętrzny związek Święta Miłosierdzia Bożego z nabożeństwem do Miłosierdzia Bożego, [en:] Święto Miłosierdzia Bożego, obra citada, p. 16-26.

2 Cfr. G. Langemeyer, Kult, [en:] Lexikon der katholischen Dogmatik, Hrsg. W. Beinert, Freiburg im Breisgau 1987, p. 337-339.

3 Cfr. E. M. Kredel, Frömmigkeit. I. Biblisch, [en:] Lexikon für Theologie und Kirche, Freiburg im Breisgau 1960, T. 4, p. 398-400. 
muertos y gloriosa Ascensión» de Cristo mediante la cual se realizó la obra de la Redención humana de la esclavitud del pecado y de la perfecta glorificación de Dios ${ }^{4}$. El cristiano participa en la adoración perfecta a Dios, realizada por Cristo, mediante la participación del sacrificio de la Santa Misa y de los sacramentos, mediante la lectura y la meditación de la Palabra de Dios, a través de la oración y el canto. Esto sucede así en virtud de las palabras de Cristo, quien prometió que estaría presente con quienes se reunieran en su nombre (Mt 18, 20) $)^{5}$. La celebración del Santísimo Sacrificio es el elemento central de adoración a Dios.

El Concilio también llama la atención sobre el hecho de que a Dios se le rinde culto en la oración privada y también en «las devociones del pueblo cristiano», que deberían estar estrechamente vinculadas con la liturgia ${ }^{6}$. Así comprendido la devoción muestra una forma especial de adoración a Dios, conocido por el creyente en el misterio que Él le desvela ${ }^{7}$.

Tratando entonces sobre las nuevas formas de devoción a la Divina Misericordia, vamos a tener en cuenta tales formas de veneración a Dios en el misterio de la misericordia que Jesucristo transmitió a la Hermana Santa Faustina en sus revelaciones privadas: La Fiesta de la Misericordia, el culto a la imagen de Jesús misericordioso, la Coronilla a la Divina Misericordia y la Hora de la Misericordia. El fundamento de estas formas de oraciones es la actitud interior llamada por la Mística de Cracovia la actitud de confianza que es la condición para rendir culto a Dios. Las nuevas formas están estrechamente vinculadas con el Misterio pascual presente en la Eucaristía que revela en plenitud al Dios de la misericordia y que no existen independientemente de él.

\section{El objeto de la devoción a la Divina Misericordia}

Al hablar de la devoción a la Divina Misericordia, pensamos en rendir culto a Dios, quien se revela al hombre en el misterio de la misericordia ${ }^{8}$. La devoción así entendida abarca todos los actos del culto cuyo objeto es Dios en persona

4 Cfr. sc 5.

Cfr. sc 7.

6 Cfr. sc 12.

7 Cfr. J. Grotz, Andacht, [en:] Lexikon der katholischen Dogmatik, Hrsg. W. Beinert, Freiburg im Breisgau, 1987, p. 502-504.

8 Cfr. I. Różycki, Miłosierdzie Boże. Zasadniczy rys nabożeństwa do Miłosierdzia Bożego (La Misericordia de Dios. Rasgos esenciales de la Devoción a la Misericordia de Dios), Kraków 1982, p. 7-8. Nabożeństwo do Miłosierdzia Bożego, Kraków 1999, p. 13-14. 
y en la Trinidad, dándose a conocer al hombre mediante sus atributos que expresan su esencia:

El lugar que ocupa la Devoción a la Misericordia Divina, en el ámbito de la devoción religiosa, que sólo se debe a Dios, está determinado por la doctrina revelada sobre la naturaleza de Dios Uno y Trino. Dios, pues, a la luz de esta doctrina, es absolutamente simple e indivisible, no hay en Él ninguna parte, es decir, todo lo que hay en Él, en su esencia, es Él mismo. Así pues, Dios no sólo es sabio, sino que es la misma Sabiduría, no sólo es omnipotente, sino que es la misma Omnipotencia; en relación al mundo, no sólo es providente, sino que es la Providencia misma; no sólo nos ama sino que es el Amor mismo; no sólo es misericordioso, sino que es la Misericordia misma. De donde, la Sabiduría, la Providencia, la Omnipotencia, el Amor y la Misericordia, que son el mismo Dios, pueden ser objeto de veneración religiosa por nuestra parte?.

La misericordia es el objeto propio de la devoción a la Divina Misericordia porque pertenece a estos atributos de Dios que definen su esencia. La misericordia de Dios en el Antiguo Testamento (hebr. hesed, rahamim, gr. eleos, latín misericordia) abarca la actitud de la compasión, de la bondad, de la piedad, de la ayuda, de la fidelidad. La verdad sobre el Dios de la misericordia la puso de relieve Jesucristo en las parábolas sobre el Buen Samaritano y del Padre misericordioso, y mostró en plenitud su grandeza con su muerte y resurreción. Santa Faustina habla muchas veces sobre la Divina Misericordia como atributo de Dios, llamándola «el mayor atributo de Dios» en su significado bíblico, es decir, la comprende como la manifestación del amor de Dios en la historia del género humano y del mundo, y sobre todo en la obra de salvación de Jesucristo. También en este espíritu define la misericordia como «amor» (Diario 1307), «bondad» (1631) y «piedad» (Diario 1148).

La grandeza de la Divina Misericordia, que es el objeto de culto en la devoción, la Mística de Cracovia la expresa mediante diferentes definiciones que acentúan la grandeza y la infinitud de Dios: «el mar insondable de la misericordia» (Diario 654), «abismo de misericordia» (Diario 85) ${ }^{10}$, «profundo océano sin límites de la misericordia», "profundidad de misericordia» (Diario 1307), «fuente de misericordia» (Diario 206). La Misericordia Divina es para la Hermana Faustina como Dios mismo: «inconcebible» (Diario 699), «insondable»

9 I. Różycki, Miłosierdzie Boże, obra citada, p. 7-8.

1o Cfr. Diario de Santa Faustina, números 88, 171, 206, 361, 438, 1146, 1188, 1666. 
(Diario 654), «impenetrable» (1146), «infinita» (Diario 697). La misericordia como atributo de Dios Uno y Trino es el atributo de las Personas Divinas: De Dios Padre, del Hijo de Dios y del Espíritu Santo (Diario 1307). Sor Faustina subraya que la misericordia «brota» de la Divina Trinidad, de «un único seno amoroso» (Diario 522).

La misericordia que sale del «seno del Padre» (Diario 949) es algo que caracteriza a Dios, quien es la fuente y el principio de todo amor, de toda vida y de toda felicidad (Diario 1122). La misericordia divina se reveló en plenitud en Jesucristo, siendo muy cercana para el hombre gracias a su sacrificio ofrecido en la cruz (Diario 522). La Divina Misericordia, presente en la muerte salvadora de Cristo, es posible llegar a conocerla gracias a la actuación del Espíritu Santo, «Espíritu de amor y de misericordia», que le permite al hombre responder al amor ilimitado de Dios (Diario 1411). De aquí que la devoción a la Divina Misericordia, refiriéndose a Dios Uno y Trino, se dirija a Dios Padre, al Hijo de Dios y al Espíritu Santo.

En las revelaciones a la Hermana Faustina se pone en primer lugar la misericordia de Jesús quien desveló al mundo la insondable misericordia de Dios. Él es llamado «Rey de misericordia» (Diario 83), «Salvador misericordioso» (Diario 1075), «Jesús misericordioso» (Diario 859), la «Misericordia Encarnada» (Diario 1745), y Su «Corazón misericordioso» (Diario 1074) es la fuente de la vida. La misericordia de Dios Uno y Trino es experimentada con mayor frecuencia como misericordia de Jesús, o de Su Corazón. Jesús como «Misericordia encarnada de Dios, es al mismo tiempo, el objeto propio de la Devoción» ${ }^{11}$. Jesús Misericordioso es no solo el «objeto propio» de la devoción, sino también el «principal», en cuanto que todos los actos del culto están concentrados en la persona de Cristo. Por consiguiente la devoción a la Divina Misericordia podemos llamarla la Devoción a Jesús Misericordioso ${ }^{12}$.

La misericordia de Dios: Del Padre, del Hijo y del Espíritu Santo es no solamente el objeto o el la meta a la que tienden los actos del culto en la devoción a la Divina Misericordia, sino también el motivo, es decir, la razón de la adoración a $\operatorname{Dios}^{13}$. La experiencia de la Divina Misericordia en la vida despierta al cristiano en primer lugar a una confianza total y permanente hacia Dios. La actitud de la confianza es el acto más esencial e interior de la devoción a la Divina Misericordia.

\footnotetext{
${ }^{11} \quad$ I. Różycki, Miłosierdzie Boże, obra citada, p. 11.

12 I. Różycki, Miłosierdzie Boże, obra citada, p. 12.

13 I. Różycki, Miłosierdzie Boże, obra citada, p. 12.
} 
En sus meditaciones sobre el tema de la devoción a la Divina Misericordia, entendida como el culto que se le rinde a Dios, el sacerdote I. Różycki habla también sobre el objeto no propio de la devoción o secundario, según el cual distingue las nuevas formas de devoción propuestas por la Hermana Santa Faustina: La imagen, la Fiesta de la Misericordia, la Coronilla y la Hora de la Misericordia ${ }^{14}$.

\section{La esencia de la devoción a la Divina Misericordia}

La condición necesaria para la devoción a la Divina Misericordia en las revelaciones a la Hermana Faustina es la confianza, llamada «recipiente», gracias al cual el hombre obtiene las gracias de la misericordia: «Las gracias de mi misericordia se toman con un solo recipiente y éste es la confianza. Cuanto más confíe un alma, tanto más recibirá. Las almas que confían sin límites son $\mathrm{Mi}$ gran consuelo, porque en tales almas vierto todos los tesoros de Mis gracias» (Diario 1578). La confianza entraña la actitud del hombre que entrega su destino a Dios, y se une a la fe en Dios y a la experiencia de su bondad ${ }^{15}$.

Ningún acto exterior de la devoción es un pleno culto que se le rinde a Dios si no va acompañado por una total confianza, y tampoco puede aportar las gracias de la Misericordia de Dios. El sacerdote I. Różycki compara esta condición al acto de arrepentimiento por los pecados, como la condición para recibir la absolución durante el sacramento de la confesión ${ }^{16}$.

A la esencia de la devoción, junto a la confianza, pertenece también el amor activo al prójimo, es decir, la práctica del amor hacia el prójimo: «Hija mía, si por medio de ti exijo de los hombres el culto a Mi misericordia, tú debes ser la primera en distinguirte por la confianza en Mi misericordia. Exijo de ti obras de misericordia que deben surgir del amor hacia Mí. Debes mostrar misericordia al prójimo siempre y en todas partes. No puedes dejar de hacerlo ni excusarte ni justificarte» (Diario 742) ${ }^{17}$. Las obras de misericordia, aseguró Jesucristo a la Hermana Faustina, pueden ser realizadas también mediante la palabra o la oración: «Te doy tres formas de ejercer misericordia al prójimo: la primera - la acción, la segunda - la palabra, la tercera - la oración. En estas

\footnotetext{
${ }^{14}$ I. Różycki, Miłosierdzie Boże, obra citada, p. 8.

15 I. Różycki, Miłosierdzie Boże, obra citada, p. 16.

16 I. Różycki, Nabożeństwo do Miłosierdzia Bożego, obra citada, p. 90.

${ }_{17}$ Cfr. Diario $1148 ; 1155 ; 1317$.
} 
tres formas está contenida la plenitud de la misericordia y es el testimonio irrefutable del amor hacia Mí» (Diario 742).

En las revelaciones de Jesús Misericordioso dirigidas a la Hermana Faustina aparece con frecuencia la expresión de que la misericordia salió del corazón de Jesús ${ }^{18}$, subrayando que el objeto de la devoción es también el Corazón divino - humano de Jesús.

La semejanza de la devoción al Corazón de Jesús con la devoción a la Divina Misericordia es sin embargo puramente externa. La diferencia entre una y otra resulta de la diferencia del objeto propio. El objeto esencial en la devoción al Corazón de Jesús es la Persona del Hijo de Dios, la Palabra Encarnada, como fuente de nueva vida, obtenida gracias a la muerte de Cristo y accesible en los sacramentos. En la devoción a la Divina Misericordia el objeto propio es la misericordia de Dios en la Santísima Trinidad: Del Padre, del Hijo y del Espíritu Santo. La Divina Misericordia como atributo de Dios se identifica con el mismo Dios y por eso es el objeto de culto. El objeto de la devoción a la Divina Misericordia se diferencia en su extensión del objeto de la devoción al Corazón de Jesús.

La diferencia entre la devoción al Corazón de Jesús y a la Divina Misericordia afecta también al objeto secundario, es decir, material. En la devoción al corazón de Jesús el objeto material del culto es el Corazón traspasado de Jesús que muestra las gracias espirituales que son el fruto de su muerte y resurreción. A pesar de que en las revelaciones a la Hermana Faustina aparece con frecuencia el Corazón de Jesús como la fuente de la misericordia, el objeto material de la devoción a la Divina Misericordia es la imagen que corresponde a las revelaciones del 22 de febrero de 1931.

La devoción al Corazón de Jesús se distingue de la devoción a la Divina Misericordia también por parte de los actos del culto. En la devoción al Corazón de Jesús los actos de adoración tienden a reparar los pecados humanos que ofenden a Dios, en cambio en la devoción a la Divina Misericordia el acto más esencial, que es el fundamento de la devoción, es la actitud de la total confianza hacia Dios.

\section{Las formas de la devoción}

En las revelaciones privadas Jesús el Señor transmitió a la Hermana Faustina las formas concretas de la devoción a la Divina Misericordia, que teniendo como

18 Diario 229, 385, 592, 1053, 1321, 1535. 
objetivo la adoración a Dios en el misterio de la misericordia se diferencian entre sí por el objeto material, es decir, dependen del modo de orar del hombre.

\section{a) La imagen}

En primer lugar Jesucristo le mostró a la Apóstol de la Divina Misericordia la imagen por medio de la cual había prometido conceder muchas gracias: «ofrezco a los hombres un recipiente con el que han de venir a la Fuente de la Misericordia para recoger gracias. Ese recipiente es esta imagen con la forma: Jesús, en Ti confío» (Diario 327). La imagen es el objeto impropio del culto en la devoción a la Divina Misericordia. Es un signo que remite a la realidad que describe, es decir, al misterio de la misericordia a cuyo servicio estuvo Cristo con su muerte y resurreción. La inscripción que se encuentra en la imagen indica la actitud de confianza en Jesús, lo cual es la esencia de la devoción, expresando la entrega total de sí mismo a Dios.

La veneración a la imagen, exigida por Jesucristo en las visiones de la Hermana Faustina, se inserta en la tradición del culto a las imágenes presente en la Iglesia Católica desde los tiempos del Concilio de Nicea II (787). La imagen no ha de representar a Dios invisible e incomprensible, sino que gracias al misterio de la Encarnación del Hijo de Dios, expresa el mensaje del Evangelio que la Sagrada Escritura describe con la ayuda de las palabras ${ }^{19}$.

La imagen de Jesús misericordioso en la devoción a la Divina misericordia cumple una doble función, siendo una herramienta tanto para Jesús el Señor como para las personas. Es entonces una herramienta para Jesús quien es la fuente verdadera de las gracias de la Divina Misericordia: «por medio de esta imagen colmaré a las almas con muchas gracias, por eso, que cada alma tenga acceso a ella» (Diario 570). Por otra parte, despertando la actitud de confianza, ayuda al hombre a abrirse a la realidad de la Divina Misericordia. Al mismo tiempo la imagen recuerda la necesidad de practicar la misericordia con el prójimo, es decir, indica el otro elemento esencial de la devoción, el cual es el cumplimiento de las obras de misericordia: «a través

19 "Siguiendo [...] la enseñanza divinamente inspirada de nuestros Santos Padres y la Tradición de la Iglesia católica (pues reconoce ser del Espíritu Santo que habita en ella), definimos con toda exactitud y cuidado que la imagen de la preciosa y vivificante cruz, así como también las venerables y santas imágenes, tanto las pintadas como las de mosaico u otra materia conveniente, se expongan en las santas iglesias de Dios, en los vasos sagrados y ornamentos, en las paredes y en cuadros, en las casas y en los caminos: tanto las imágenes de nuestro Señor Dios y Salvador Jesucristo, como las de nuestra Señora Inmaculada la Santa Madre de Dios, de los santos ángeles y de todos los santos y justos". 
de esta imagen concederé muchas gracias a las almas; ella ha de recordar a los hombres las exigencias de Mi misericordia, porque la fe sin obras, por fuerte que sea, es inútil» (Diario 742). La imagen enseña que la adoración total a la Divina Misericordia se realiza entonces cuando el hombre se dirige hacia Dios en una actitud de confianza confirmando la actitud interior con la obra de misericordia.

La realidad a la cual se remite el creyente durante la devoción a la Divina Misericordia, expresada en la imagen pintada bajo la influencia de la visión de la Hermana Faustina, fue explicada por Jesucristo en las posteriores apariciones: «...Los dos rayos significan la Sangre y el Agua. El rayo pálido simboliza el Agua que justifica a las almas. El rayo rojo simboliza la Sangre que es la vida de las almas...» (Diario 299). Los rayos en la imagen de Jesús Misericordioso, por analogía a la Sangre y al Agua, las cuales según la descripción de San Juan Evangelista salieron del costado abierto de Cristo (cfr Jn 19, 34-37), muestran las gracias de la misericordia a las cuales Cristo prestó su servicio mediante su muerte y resurreción. Estas gracias están a disposición del hombre de un modo especial en los sacramentos del Bautismo, de la Penitencia y de la Eucaristía. Se puede decir entonces que la imagen por su contenido muestra el objeto propio de la devoción a la Divina Misericordia, es decir, la muerte de Jesús y su valor salvífico, la cual es la fuente de la misericordia ${ }^{20}$.

La imagen de Jesús Misericordioso, según las palabras de Jesucristo, debería de ser venerada públicamente en la capilla del monasterio y en todo el mundo: «Deseo que esta imagen sea venerada primero en su capilla y [luego] en el mundo entero» (Diario 47). De este modo la devoción a la Divina Misericordia tiene que abarcar a todas las personas quienes por medio de la imagen se abran a la actuación de la misericordia. Las revelaciones precisan también que el acto de bendición de la imagen tiene que ser en «el primer domingo después de la Pascua de Resurreción» (Diario 49), vinculando la veneración de la imagen con la celebración de la Fiesta de la Misericordia.

\section{b) La Fiesta de la Misericordia}

El lugar central en la devoción a la Divina Misericordia lo ocupa la Fiesta de la Misericordia que según la visión de la Hermana Faustina debería ser celebrada el primer domingo después de Pascua de Resurreción (Diario 49). La unión de la Fiesta de la Misericordia con las celebraciones de Pascua indica el vínculo

20 I. Różycki, Nabożeństwo do Bożego Miłosierdzia, obra citada, p. 96. 
estrecho de la Divina Misericordia con el Misterio Pascual: «Ahora veo que la obra de la Redención está ligada a la obra de la misericordia que reclama el Señor» (Diario 89). El objeto de la Fiesta de la Misericordia es la misericordia de Dios que fue plenamente revelada al mundo en la muerte y resurreción de Cristo. La celebración exterior es un modo de acercarse al misterio de la Divina Misericordia y a abrirse a su actuación.

La preparación para la Fiesta de la Misericordia es la novena que consiste en el rezo de la Coronilla a la Divina Misericordia (Diario 796), ofrecida por diferentes personas (Diario 1209-1229). La celebración de la Fiesta consiste en la bendición de la imagen de la Divina Misericordia (Diario 49), en su veneración pública que ha de ser la misma a como se veneran las imágenes en la Iglesia Católica (Diario 414), así como en la predicación del sermón durante el cual los sacerdotes deberían hablar de la insondable Divina Misericordia para despertar en el corazón la actitud de confianza (Diario 520). En ese día los fieles han de acudir a la «Fuente de la Vida» (Diario 300), es decir, a «la confesión y a la santa Comunión» (Diario 699), para obtener las gracias especiales «el perdón total de las culpas y de las penas» (Diario 300, 699).

La Fiesta de la Divina Misericordia, esencialmente vinculada con la celebración del Misterio Pascual, debería convertirse en la oportunidad de mostrar al mundo la Misericordia de Dios y ayudar a que todos se acerquen a ella, especialmente los pecadores: «Deseo que la Fiesta de la Misericordia sea refugio y amparo para todas las almas y, especialmente, para los pobres pecadores. Ese día están abiertas las entrañas de Mi misericordia. Derramo todo un mar de gracias sobre las almas que se acercan al manantial de Mi misericordia» (Diario 699). La Fiesta de la Misericordia abarca a una extensa multitud de personas que con confianza se dirijan a Dios.

Desde el 30 de abril de 2000, día de la canonización de la Hermana Faustina, en vigor de la decisión del Santo Padre Juan Pablo is, la Fiesta de la Divina Misericordia fue introducida en el calendario litúrgico de toda la Iglesia Católica.

\section{c) La Coronilla a la Misericordia}

Junto a la Fiesta de la Misericordia y a la imagen de Jesús Misericordioso, un lugar importante en la devoción a la Divina Misericordia lo ocupa la Coronilla que Jesús el Señor transmitió a la Hermana Faustina. Jesucristo se remitió a la tradición de la Congregación de las Hermanas de la Madre de Dios de la Misericordia, que practicaba la coronilla consistente en el rezo del Padre nuestro, el Ave María, el acto ¡Señor Jesucristo a quien no hay nada semejante, tan solo compadécete de nosotros que mendigamos tu misericordia, 
¡ten piedad de nosotros!, la jaculatoria repetida diez veces ¡Oh Jesús mío!, Misericordia, la oración Gloria al Padre, y al final Padre Nuestro, Ave María $y$ Creo en Dios ${ }^{21}$.

Según la visión la Coronilla debía ser rezada con el rosario, comenzando con la oración del Padre Nuestro, Dios te salve María y Creo en Dios. Se compone de las palabras: «Padre Eterno, Te ofrezco el Cuerpo y la Sangre, el Alma y la Divinidad de tu Amadísimo Hijo, nuestro Señor Jesucristo, como propiciación de nuestros pecados y los del mundo entero», rezadas en las cuentas correspondientes al Padre nuestro, y en las cuentas del Ave María la oración: «Por su dolorosa Pasión, ten misericordia de nosotros y del mundo entero». Al final se reza tres veces la oración: «Santo Dios, Santo Fuerte, Santo Inmortal, ten piedad de nosotros y del mundo entero» (Diario 476).

En la oración Padre Eterno la persona que ora se dirige a Dios Padre uniéndose con el Sacrificio de Cristo ( «Te ofrezco el Cuerpo y la Sangre, el Alma y la Divinidad de tu Amadísimo Hijo») realizado en la cruz para la salvación del género humano («por nuestros pecados y los del mundo entero»). De este modo se dirige a la Divina Misericordia que es el objeto propio de la devoción. También en la segunda fórmula de la oración - Por su dolorosa Pasión - la persona que ora se dirige a los méritos de la pasión de Cristo por medio de la cual el hombre llega participar de la misericordia. Una forma parecida a dicha oración es la que surgió en las revelaciones a la Hermana Lucía de Fátima, con la única diferencia de que esta última se dirige a la Santísima Trinidad.

La condición para obtener las gracias en la oración de la Coronilla, igual que en la veneración de la imagen de Jesús Misericordioso y de la celebración de la Fiesta de la Misericordia, es la confianza. El rezo de la Coronilla es una forma especial de adoración a la Divina Misericordia y de la propagación del culto a la misericordia, semejante a la oración del rosario.

\section{d) La hora de la Misericordia}

La Hora de la Misericordia es la hora de la muerte de Cristo, de la cual hablan los Evangelistas, vinculándola con las tres de la tarde (Mc 15, 33). En la tradición de la Congregación de las Hermanas de la Madre de Dios de la Misericordia cada hermana era animada por las Constituciones a dar culto al Salvador a las tres de la tarde. Esto debería de expresarse mediante el gesto de arrodillarse

${ }^{21}$ E. Siepak zмвм, Kult Miłosierdzia Bożego w Zgromadzeniu Sióstr Matki Bożej Miłosierdzia, [en:] Posłannictwo Siostry Faustyny, obra citada, p. 252. 
y con la frente sobre tierra, así como con una corta oración de adoración ${ }^{22}$. A la práctica de esta oración se remitió Jesús el Señor en algunas visiones, animando a su discípula a la Hora de la Misericordia.

Jesús el Señor en una visión ordenó a la Hermana Faustina meditar su Pasión y acompañarlo en su sufrimiento: «A las tres ruega por Mi misericordia, en especial para los pecadores y aunque sólo sea por un brevísimo momento, sumérgete en Mi pasión, especialmente en Mi abandono en el momento de Mi agonía» (Diario 1320). A la meditación del sufrimiento y de la muerte hay que añadir la oración en intención de todo el mundo y de los pecadores, que debería ser dirigida a Dios por los méritos de la Pasión de Cristo («pedir por la Pasión de Cristo»). A continuación en las visiones posteriores le explicó a su discípula que la meditación sobre la pasión de Cristo a las tres de la tarde podía consistir en la celebración del vía crucis, si la persona en oración dispusiera del tiempo y de la posibilidad para ir a la capilla. Puede ser también un breve momento de reflexión sobre el sufrimiento de Jesús (Diario 1572). Cada una de estas oraciones ha de ser una adoración a Dios y una invocación de su omnipotencia.

\section{Las promesas vinculadas con la propagación del culto a la Divina Misericordia}

El fin de la devoción a la Divina Misericordia es rendir culto a Dios en el misterio de la misericordia. En las nuevas formas de oración que forman parte de la devoción a la Divina Misericordia aparece muchas veces la afirmación de que ellas son un modo de adoración al Dios de la misericordia y de la propagación del culto a la Divina Misericordia. Ya el mismo hecho de dirigirse a la misericordia Divina es rendirle gloria a Dios (Diario 378).

En las revelaciones privadas Jesucristo vinculó con la propagación de la devoción a la Divina Misericordia las promesas de una protección especial y la experiencia de la misericordia en la hora de la muerte: «...Con las almas que glorifiquen y proclamen Mi gran misericordia a los demás, en la hora de la muerte Me comportaré según Mi infinita misericordia» (Diario 379). Una gracia especial en cuanto a la eficacia de la palabra y el ablandamiento de los corazones empedernidos se la prometió Jesucristo a los sacerdotes que «proclamen y alaben» la misericordia de Dios (Diario 1521).

${ }^{22}$ E. Siepak zмвм, Kult Miłosierdzia Bożego w Zgromadzeniu Sióstr Matki Bożej Miłosierdzia, [en:] Posłannictwo Siostry Faustyny, obra citada, p. 251. 
Con la veneración de la imagen de Jesús Misericordioso están relacionadas las promesas que Jesucristo vinculó con esta devoción: «Prometo que el alma que venere esta imagen no perecerá. También prometo, ya aquí en la tierra, la victoria sobre los enemigos y, sobre todo, a la hora de la muerte. Yo Mismo la defenderé como Mi gloria» (Diario 48). La primera promesa procedente de la veneración de la imagen de Jesús Misericordioso es la salvación eterna («no perecerá»), lo cual es un bien merecido por Cristo. La segunda promesa concierne a la gracia especial en la lucha contra el mal ( «la victoria sobre el mal y, sobre todo, a la hora de la muerte»), y el progreso en la vida espiritual, así como la gracia de la buena muerte. El sacerdote I. Różycki señala todavía las promesas relacionadas con la veneración de la imagen de la Divina Misericordia que proceden de la apertura del corazón a Dios en actitud de confianza. Ellas comprenden, como anteriormente, la gracia de la salvación eterna: "Quien confía en Mi misericordia no perecerá porque todos sus asuntos son Míos» (Diario 723), así como «gracias inconcebibles», es decir las gracias necesarias en la vida diaria.

Las promesas relacionadas con la celebración de la Fiesta de la Misericordia tienen un carácter excepcional primeramente porque fueron relacionadas con el día concreto del primer domingo después de Pascua, perteneciente a la Octava de Pascua. Las gracias que prometió Jesucristo en las visiones están condicionadas a «confesarse y recibir la Santa Comunión» (Diario 699). El sacerdote I Różycki observó que a la confesión se puede acudir antes para estar en el estado de la gracia santificante, en cambio la Santa Comunión hay que recibirla en el día de la Fiesta de la Misericordia ${ }^{23}$. Las gracias de la Fiesta de la Misericordia comprenden la absolución total de todos los pecados todavía no absueltos hasta el momento, así como la absolución total de todas las penas que son la consecuencia de estos pecados ${ }^{24}$. Comparando estas gracias con la gracia del bautismo, el sacerdote Różycki subrayó que desde el punto de vista teológico ellas son posibles permaneciendo en el misterio de Dios.

La Fiesta de la Misericordia debería convertirse en «refugio y amparo para todos los pecadores» (Diario 699), así como en una oportunidad para obtener muchas otras gracias que no fueron definidas de forma más aproximada: «En ese día están abiertas las entrañas de Mi misericordia. Derramo todo un mar de gracias sobre las almas que se acercan al manantial de Mi misericordia»

23 I. Różycki, Nabożeństwo do Bożego Miłosierdzia, obra citada, p. 101-102.

${ }^{24}$ I. Różycki, Nabożeństwo do Bożego Miłosierdzia, obra citada, p. 102. 
(Diario 699). En esta promesa fue subrayado el carácter universal de las gracias concedidas por Dios en el día de la Fiesta de la Divina Misericordia.

La primera promesa vinculada con el rezo de la Coronilla es la gracia de alcanzar «una gran misericordia a la hora de la muerte» (Diario 687) que consiste en la conversión y en la muerte en estado de gracia. Una gracia semejante al «aplacamiento de la ira divina» y a la conversión la prometió Jesucristo mediante el rezo de la Coronilla por los agonizantes (Diario 811). Según el sacerdote I. Różycki esta gracia consiste en la absolución de los pecados y en «la vuelta al estado de gracia $»^{25}$. La tercera promesa habla de la gracia de la paz del alma y de la muerte dichosa para quien en el momento de la muerte rece él mismo la Coronilla: «A quienes recen esta coronilla, Me complazco en darles lo que Me pidan» (Diario 1541). Esta gracia es semejante a la necesaria, es decir, a la absolución de los pecados: «Escribe: cuando recen esta coronilla junto a los moribundos, Me pondré entre el Padre y el alma agonizante no como el Juez justo sino como el Salvador misericordioso» (Diario 1541). Considerando que las promesas conciernen al momento de la muerte, importante para cada hombre, los sacerdotes deberían proponer la Coronilla como «la última tabla de salvación» (Diario 687). La condición para la obtención de las gracias mediante el rezo de la Coronilla es la conformidad de la petición con la voluntad de Dios. (Diario 1731).

Con la oración en la Hora de la Misericordia Jesucristo vinculó la gracia de una comprensión más profunda de su pasión, así como todas las gracias necesarias para el alma («en esta hora nada le será negado al alma» Diario 1320), ya que en ese momento la misericordia se abrió «de par en par» (Diario 1572).

Las promesas relacionadas con la devoción a la Divina Misericordia y con las nuevas formas de las oraciones transmitidas por Santa Faustina abarcan sobre todo la gracia de la conversión para los pecadores y la reconciliación con Dios, la gracia del cuidado especial en la hora de la muerte y la vida eterna, la gracia de la absolución de las culpas y de las penas, unida al sacramento de la penitencia y a la Santa Comunión. Las gracias especiales que Jesucristo prometió para todos los que den culto a la Divina Misericordia y propaguen el culto a la Divina Misericordia, son el cuidado en la vida y la defensa contra los ataques de Satanás. A los sacerdotes que proclamen la Misericordia de Dios en sus sermones y que participen en la distribución de la misericordia en el sacramento de la penitencia, el Jesús de los corazones les aseguró la gracia del «arrepentimiento de los corazones».

\footnotetext{
25 I. Różycki, Nabożeństwo do Bożego Miłosierdzia, obra citada, p. 114.
} 
La devoción a la Divina Misericordia como una forma de culto a Dios tiene como objeto propio a Dios en el misterio de la misericordia y se inserta en la tradición de la piedad cristiana, convirtiéndose en su prolongación y en su enriquecimiento. Se dirige a la misericordia del Padre, revelado plenamente en la pasión, en la muerte y en la resurreción de Cristo y se basa en la actitud de confianza en Dios.

Las nuevas formas de devoción propuestas por la Hermana Faustina en base a las revelaciones privadas que obtuvo de Jesús se convierten en una oportunidad de adorar a Dios y en una apertura a su actuación. La canonización de Santa Faustina Kowalska y la institución de la Fiesta de la Misericordia para toda la Iglesia son una indicación clara del Santo Padre Juan Pablo II para emprender estas formas de devoción en la Liturgia de la Iglesia, así como en la animación a los fieles para que se beneficien de ellas en su piedad privada.

\section{BiBLIOGRAFIA}

Faustyna Kowalska, Dzienniczek. Miłosierdzie Boże w duszy mojej, Kraków 1983. Juan Pablo II, Encíclica Dives in misericordia, 1981.

Machniak J., Doświadczenie Boga w tajemnicy Jego miłosierdzia u św. Faustyny Kowalskiej, Kraków 1998.

Dziadosz H., Miłosierdzie Boże na nowo odkrywane, Kraków 1999.

Siepak E., Dłubak N., Duchowość św. Faustyny, Kraków 2000.

Sopoćko M., Miłosierdzie Boga w dziełach Jego, Londyn 1959.

\section{REASUMIDO}

\section{La devoción a la Divina Misericordia segun Sancta Faustina Kowalska}

La devoción a la Divina Misericordia como una forma de culto a Dios tiene como objeto propio a Dios en el misterio de la misericordia y se inserta en la tradición de la piedad cristiana, convirtiéndose en su prolongación y en su enriquecimiento. Se dirige a la misericordia del Padre, revelado plenamente en la pasión, en la muerte y en la resurreción de Cristo y se basa en la actitud de confianza en Dios.

Las nuevas formas de devoción propuestas por la Hermana Faustina en base a las revelaciones privadas que obtuvo de Jesús se convierten en una oportunidad de adorar a Dios y en una apertura a su actuación. La canonización de Santa Faustina Kowalska y la institución de la Fiesta de la Misericordia para toda la Iglesia son una indicación clara del Santo Padre Juan Pablo in para emprender estas formas de devoción en la 
Liturgia de la Iglesia, así como en la animación a los fieles para que se beneficien de ellas en su piedad privada.

\section{Palabras llaves}

Divina Misericordia, Hermana Faustina, Liturgia de la Iglesia, Coronilla a la Divina Miericordia, imagen de Jesus Misericordioso

\section{Abstract}

\section{Devotion to the Divine Mercy. According to Faustina Kowalska}

The devotion to Divine Mercy is one form of the cult of God with the proper object, which is God in the Mystery of the Holy Trinity. It is the part of the Christian piety directed to God Father, who revealed his Mercy in the death and resurrection of Jesus Christ.

The new forms of the devotion to Divine Mercy proposed by Saint Sister Faustina contains the Feast of Divine Merci, celebrated on Mercy Sunday, the veneration of the image of Merciful Jesus and the Chaplet to Divine Mercy. John Paul II in the canonization of Sister Faustina proposed this devotion to the entire Church.

\section{KEYWORDS}

divine mercy, parish, Sister Faustina, Catholic Church 